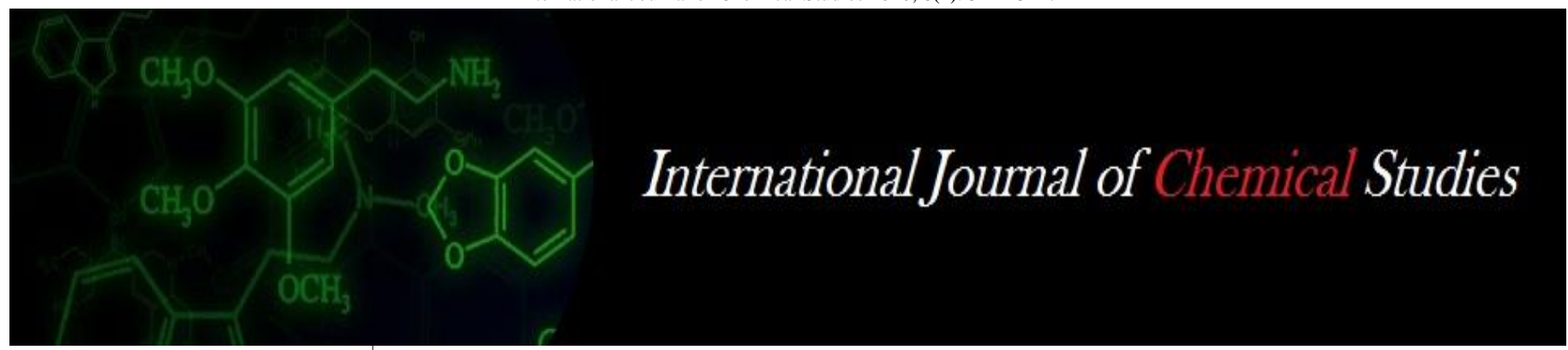

P-ISSN: 2349-8528

E-ISSN: 2321-4902

www.chemijournal.com

IJCS 2020; 8(4): 3214-3217

(C) 2020 IJCS

Received: 11-05-2020

Accepted: 13-06-2020

\section{Vomendra Kumar}

Department of Soil Science \&

Agricultural Chemistry, IGKV,

Raipur, Chhattisgarh, India

\section{Anurag}

Department of Soil Science \& Agricultural Chemistry, IGKV,

Raipur, Chhattisgarh, India

\section{RN Singh}

Department of Soil Science \& Agricultural Chemistry, IGKV, Raipur, Chhattisgarh, India

\section{Rahul Kumar}

College of Agriculture,

Bharatpur, Rajasthan, India

\section{Kulendra Jaiswal}

Department of Soil Science \& Agricultural Chemistry, IGKV, Raipur, Chhattisgarh, India

\section{Effect of rice residues and organics source on physico-chemical properties of the soil}

\author{
Vomendra Kumar, Anurag, RN Singh, Rahul Kumar and Kulendra \\ Jaiswal
}

DOI: https://doi.org/10.22271/chemi.2020.v8.i4an.10148

\begin{abstract}
The study entitled was carried out during Kharif season of 2018-2019 at Research farm of, Indira Gandhi krishi Vishwavidhyalaya, Raipur, Chhattisgarh. The experiment was laid out in randomized block design three replication and ten treatment combinations rice residue with organic source. The treatment combination for rice were T1 [Control (N0:P0:K0], T2 [100\% NPK (100:60:40)], T3 [100\% Rice Residue], T4 [150\% Rice Residue], T5 [50\% N Rice Residue + 50\% N Green Manure], T6 [75\% N Rice Residue $+25 \%$ N Green Manure], T7 [50\% N Rice Residue + 50\% N Vermicompost], T8 [75\% N Rice Residue $+25 \%$ N Vermicompost], T9 [100\% N Rice Residue + BGA+ Azospirillum], T10 [150\% N Rice Residue + BGA+ Azospirillum]. The incorporation of rice residue with organics reduced the bulk density and increased porosity of soil. While the soil $\mathrm{pH}$ was non significantly increased but Organic Carbon and electrical conductivity were significantly increased in incorporation of rice residue along with organics. The available nitrogen, phosphorus, potassium and micro nutrient iron, copper, manganese and zinc status in soil was not significantly influenced due to the incorporation of rice residue. In present study it is clearly indicated that incorporation of rice residue along with organics had higher yield as well as maintained soil physico- chemical and biological properties.
\end{abstract}

Keywords: Physico-chemical, rice residues, Kharif

\section{Introduction}

Crop residues are those portions of the crop which is left out in field after harvesting and threshing of the crop. The crop residue may or may not be utilised by the farmer. The crop residue has some precious nutrient contents which can be utilised by crop by proper management practices. The crop residue are considered as waste material but after scientific or tradition management it becomes useful and it helps in nutrient recycling by providing some nutrients to soil and plant. It is less investment with high profit deal without any environmental degradation instead of that it is organic in nature and helps in the improving soil physical, chemical and biological property of the soil. It improves the soil dynamics by increasing the organic carbon and organic matter content in the soil. It becomes the source of nutrition for the growth and development of the microorganisms. It helps in sustainable and ecological growth of the farmer by healthy soil and environment.

Various farming activities adopted by farmer are the major causes of the reduction in the soil organic matter as well as reduction in soil quality due to improper utilization of the land and inorganic fertilizer. Soil organic matter plays a vital role in the improvement of the physical, chemical and biological properties of the soil. The soil organic matter has a direct correlation with the other nutrient content in the soil. Soil organic matter increases the soil dynamics and also establish positive correlative with the environment (Dalal and Mayer, 1986) ${ }^{\text {[6] }}$. Crop residues are important sources of essential plant nutrients which is important components for the stability of agricultural ecosystems and their ecology.

Rice straw is best well known for their nutrients (Ponnamperuma, 1982) ${ }^{[13]}$. During the harvesting of the rice crop its straw is placed in soil itself and about $15 \mathrm{~cm}$ crop residue are left in the field. The straw content left in the field is serious problem and it creates burden over the soil for their decomposition because a very short gap available between the harvesting of the rice crop and cultivation of the wheat crop. Stubble burning, is a traditional practice commonly aimed at controlling the soil borne crop diseases, is a common practice in India particularly in 
an area where, there is a short fallow period or scarcity of water. Although such practice of stubble management does not reportedly affect the wheat yield adversely, the stubble burning is not scientific method for proper disposal of the straw and even it causes loss of energy and environmental pollution. Besides, crop burning of the stubble also causes loss of organic matter and plant nutrients.

\section{Materials and Methods \\ Site description}

The study (2018-19) on RCS was conducted at the research farm of the IGKV, Raipur and Chhattisgarh, India. The experimental site is situated in plains of Chhattisgarh at Eastern part of Raipur and it's located between $20^{\circ} 4^{0}$ North latitude and $81^{0} 39^{\circ}$ East longitudes with an altitude of $293 \mathrm{~m}$ above mean sea level. The soil of experimental site is represented as a Typic chromesterts (Vertisols) (Arang-I series). It is locally called Kanhar. The soil is characterized by silty clay texture and moderate to slow internal drainage, medium to deep depth, and brownish gray in surface color, sub angular to angular, blocky structure and neutral in reaction. The top-soil $(0-15 \mathrm{~cm}$ layer $)$ at the start of experiment was neutral (electrical conductivity $0.14 \mathrm{dSm}^{-1}$ ) with $\mathrm{pH}$ 6.95, and contained $0.60 \%$ Walkley-Black carbon, $225 \mathrm{~kg} \mathrm{ha}^{-1}$ available N (Subbiah and Asija, 1956) ${ }^{[17]}, 23.8 \mathrm{~kg}$ ha $^{-1} 0.5 \mathrm{M}$ NaHCO3-extractable P (Olsen et al., 1954) ${ }^{[10]}$ and $403 \mathrm{~kg} \mathrm{ha}^{-1} 1 \mathrm{~N} \mathrm{NH}_{4} \mathrm{OAc}$-extractable $\mathrm{K}$.

\section{Experimental details}

The experiment was laid out in a randomized plot design with a total of ten treatments replicated three times. T1 [Control (N0:P0:K0], T2 [100\% NPK (100:60:40)], T3 [100\% Rice Residue], T4 [150\% Rice Residue], T5 [50\% N Rice Residue $+50 \%$ N Green Manure],T6 [75\% N Rice Residue + 25\% N Green Manure],T7 [50\% N Rice Residue $+50 \% \mathrm{~N}$ Vermicompost], T8 [75\% N Rice Residue $+25 \% \mathrm{~N}$ Vermicompost], T9 [100\% N Rice Residue + BGA+ Azospirillum], T10 [150\% N Rice Residue + BGA+ Azospirillum]. The soil bulk density at $0-15 \mathrm{~cm}$ depths was measured on undisturbed soil cores (Blake and Hartge, 1986) [4]. All data were analyzed by analyses of variance (ANOVA) in a randomized plot design. The treatment means were compared using least significant differences for the effects as well as comparison of one and other treatments (Gomez and Gomez, 1984).

\section{Results and discussion}

\section{Bulk density, Porosity and pH}

The data presented in Table 1. revealed that, the bulk density of soil was non significantly influenced by rice residue management. The lowest soil bulk density (1.30 Mg m-3) was recorded under $\mathrm{T}-10[150 \% \mathrm{RR}+\mathrm{BGA}+$ Azospirillum $]$ and the highest soil bulk density (1.45 Mg m-3) was recorded under T1 [control]. The incorporation of crop residues decreased the bulk density may be due to addition of organic matter and subsequent increase in porosity of soil. Similar results were reported by Walia et al. (1995) ${ }^{[19]}$ and Belakki et al. (1998) ${ }^{[1]}$ The data presented in Table 1. revealed that, the porosity of soil was non significantly changed by rice residue incorporation The effect of various combination of different level of rice residue incorporation did not change significantly among the treatments

\section{Electrical conductivity and Organic carbon}

The data of electrical conductivity and organic Carbon presented in Table 1. indicated that the incorporation of rice residue caused increase in the electrical conductivity and organic carbon of soil irrespective of initial value $\left(0.22 \mathrm{dSm}^{-}\right.$ $\left.{ }^{1}\right)$. The e highest value of organic carbon $(0.67 \%)$ was recorded with the soil organic carbon content was increased due to incorporation of organic materials. Similar results were reported by Gangaiah et al. (1999) ${ }^{[7]}$, Regar et al. (2005) ${ }^{[14]}$ and Singh et al. (2009) ${ }^{[15]}$.

\section{Soil available nitrogen, phosphorus and potassium}

The data of soil available nitrogen, available phosphorus status $\left(\mathrm{kg} \mathrm{ha}^{-1}\right)$, are presented in Table 2 . It is revealed that the soil available nitrogen, phosphorus status was not significantly influenced due to incorporation of crop residue. The highest available nitrogen (259 $\left.\mathrm{kg} \mathrm{ha}^{-1}\right)$, phosphorus status $\left(18 \mathrm{~kg} \mathrm{ha}^{-1}\right)$ was recorded under T8 and the highest soil available potassium status (359 $\left.\mathrm{kg} \mathrm{ha}^{-1}\right)$ was recorded in T10. Similar results were reported by Prasad and Sinha (2000) ${ }^{[12]}$ and Surekha et al. (2004) ${ }^{[16]}$.

\section{Soil available Micronutrients}

The data presented in Table 2. showed that the available iron, manganese and copper status of soil was non significantly influenced due to incorporation of rice residue over the treatments. The highest soil available iron iron $\left(27 \mathrm{mg} \mathrm{kg}^{-1}\right)$, manganese manganese $\left(22 \mathrm{mg} \mathrm{kg}^{-1}\right)$ and copper status $(2.6 \mathrm{mg}$ $\mathrm{kg}^{-1}$ ) was recorded under treatment T10 [Rice residue $150 \%+$ $\mathrm{BGA}+$ Azospirillum]. And the result showed the available zinc content in soil was non significantly affected due to incorporation of rice residue over the treatments. The highest value of available zinc status was recorded under T2 [ $(0.6 \mathrm{mg}$ $\left.\mathrm{kg}^{-1}\right) \mathrm{RDF}$ ], T4 [(0.6 mg kg-1) Rice residue 100\%] and T 10 [0.6 mg kg-1) Rice residue $150 \%+$ BGA + Azospirillum].

Table 1: Effect of rice residues with different organics on Bulk density, Porosity (\%), pH, EC and OC (\%) of the soil after harvest of rice crop

\begin{tabular}{|c|c|c|c|c|c|}
\hline \multirow{2}{*}{ Treatments } & \multirow{2}{*}{ Bulk density $\left(\mathrm{mg} / \mathrm{m}^{3}\right)$} & Porosity (\%) & pH & EC(dsm-1) & OC \% \\
\hline & & & & & \\
\hline T1- Control & 1.45 & 37 & 7.2 & 0.27 & 0.57 \\
\hline T2- RDF & 1.43 & 38 & 7.2 & 0.26 & 0.60 \\
\hline T3- 100\% RR & 1.35 & 41 & 7.2 & 0.32 & 0.63 \\
\hline T4- $150 \%$ RR & 1.32 & 42 & 7.4 & 0.36 & 0.64 \\
\hline T5- 50\% RR+ 50\% GM & 1.40 & 39 & 7.2 & 0.28 & 0.59 \\
\hline T6- $75 \% \mathrm{RR}+25 \% \mathrm{GM}$ & 1.39 & 39 & 7.2 & 0.32 & 0.59 \\
\hline $\mathrm{T} 7-50 \% \mathrm{RR}+50 \% \mathrm{VC}$ & 1.42 & 38 & 7.5 & 0.28 & 0.58 \\
\hline $\mathrm{T} 8-75 \% \mathrm{RR}+25 \% \mathrm{VC}$ & 1.41 & 38 & 7.4 & 0.28 & 0.63 \\
\hline T9- 100\% RR+ BGA+ Azospirillum & 1.34 & 42 & 7.3 & 0.25 & 0.61 \\
\hline T10- 150\% RR+ BGA+ Azospirillum & 1.30 & 43 & 7.4 & 0.28 & 0.67 \\
\hline C.D at $5 \%$ & NS & NS & NS & .003 & .006 \\
\hline
\end{tabular}


Table 2: Effect of rice residues with different organics on Available N,P,K and micronutrient of the soil after harvest of rice crop

\begin{tabular}{|c|c|c|c|c|c|c|c|}
\hline Treatments & N Kg ha $^{-1}$ & P Kg ha-1 & $\mathrm{K} \mathrm{Kg} \mathrm{ha}^{-1}$ & Fe mg kg-1 & Mn mg kg-1 & Cu mg kg-1 & $\mathrm{Zn} \mathrm{mg} \mathrm{kg}^{-1}$ \\
\hline T1- Control & 243 & 15 & 340 & 15 & 15 & 0.2 & 1.8 \\
\hline T2- RDF & 258 & 17 & 356 & 20 & 17 & 0.6 & 2.0 \\
\hline T3- 100\% RR & 245 & 16 & 349 & 18 & 19 & 0.4 & 2.2 \\
\hline T4- $150 \%$ RR & 248 & 16 & 358 & 26 & 21 & 0.6 & 2.3 \\
\hline T5- 50\% RR+ 50\% GM & 248 & 17 & 355 & 22 & 18 & 0.5 & 2.4 \\
\hline T6- 75\% RR+ 25\% GM & 258 & 16 & 357 & 26 & 19 & 0.5 & 2.5 \\
\hline $\mathrm{T} 7-50 \% \mathrm{RR}+50 \% \mathrm{VC}$ & 253 & 17 & 345 & 25 & 21 & 0.5 & 2.2 \\
\hline $\mathrm{T} 8-75 \% \mathrm{RR}+25 \% \mathrm{VC}$ & 259 & 18 & 350 & 24 & 19 & 0.5 & 2.1 \\
\hline T9- 100\% RR+ BGA+ Azospirillum & 253 & 16 & 353 & 25 & 19 & 0.4 & 2.3 \\
\hline T10- 150\% RR+ BGA+ Azospirillum & 256 & 16 & 359 & 27 & 21 & 0.6 & 2.6 \\
\hline C.D at $5 \%$ & NS & NS & NS & NS & NS & NS & NS \\
\hline
\end{tabular}
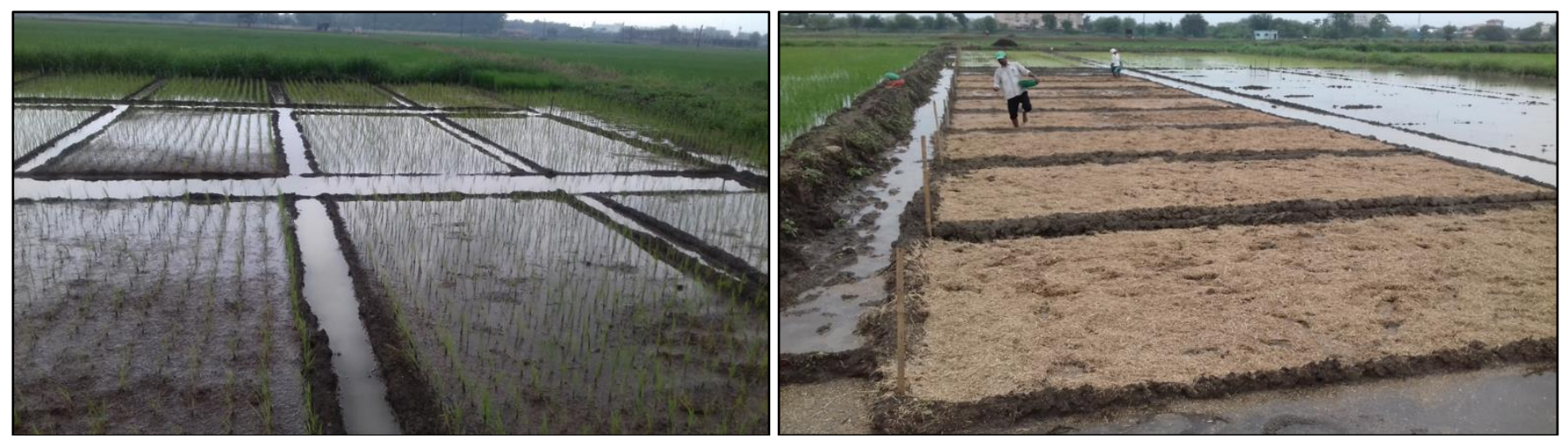

Plate 1: Glimpses of Experiment

\section{Conclusion}

The incorporation of rice residue along with different organic manures and fertilizer like, Rice residue, Vermicomposting, green manure, BGA, Azospirillum, and urea, DAP, MOP had improved the physico-chemical properties of soil i.e. there is the reduction in bulk density and increased the soil porosity and organic carbon status of the soil.

Whereas non significantly change was observed in $\mathrm{pH}$ however the electrical conductivity was significantly higher as compared to initial status of the soil. The incorporation of rice residue along with different organic manures had non significantly change the available major nutrients (N, P and $\mathrm{K})$ and micronutrients ( $\mathrm{Fe}, \mathrm{Zn}, \mathrm{Cu}$ and $\mathrm{Mn}$ ) in the soil.

\section{References}

1. Bellakki MA, Badanur VP, Setty RA. Effect of long-term integratednutrient management on some important properties of a Vertisol. Journal of the Indian Society of Soil Science. 1998; 46:176-180

2. Black CA. Method of soil analysis. American Society of Agronomy, Madison, Wisconsin, USA, 1965, 131-137.

3. Black CA. Methods of soil analysis, Part 1 and 2. Agronomy Monograph no. 3 in the series "Agronomy". American Soc. Agron., Inc., Madison, Wisconsin, U.S.A, 1966.

4. Blake GR, Hartge. Bulk density, In: Methods of Soil Analysis, Part-I (Ed. A. Klute) ASA Agronomy monograph. Madison Wisconsin, USA, 1986, 63-378.

5. Brar AS, Walia US. Influence of rice residue management techniques on physical properties of soil and root density of wheat (Triticum aestivum L.). J Res Punjab agric University. 2010; 47:25-29.

6. Dalal RC, Mayer RJ. Long term trends in fertility of soils under continuous cultivation and cereal cropping in southern Queensland. V. Rate of loss of total nitrogen from the soil profile and changes in carbon: nitrogen ratios. Soil Research. 1986; 24(4):493-504.
7. Gangaiah B, Prasad R, Prasad R. Effect of wheat residue management practices and fertilizers on productivity, nutrient removal and soil fertility of rice-wheat sequence. Journal of Soils and Crops. 1999; 6:10-13.

8. Hanway JJ, H Heidel. Soil Analysis Methods, as used in Iowa State. College Soil Testing Laboratory, Iowa, Agriculture. 1952; 57:1-31.

9. Lindsay WL, Norvell WA. Development of DTPA soil testing for Zinc,iron,manganese and copper. Soil Science Society of America Journal. 1978; 42:421-428

10. Olsen SR, Cole CV, Watanabe FS, Dean LA. Estimation of available Phosphorus in soils by extraction with sodium bicarbonate.United State Department of Agriculture, Circular. 1954; 19:939.

11. Piper CS. Soil and Plant Anaslysis. Academic Press, New York, 1967, 368.

12. Prasad B, Sinha SK. Long-term effects of fertilizers and organic manures on crop yields, nutrient balance and soil properties in rice - wheat cropping system in Bihar. Rice -Wheat Consortium Paper Series 6. New Delhi, India: Rice - Wheat Consortium for the Indo-Gangetic Plains, 2000, 105119.

13. Ponnamperuma FN. Straw as a Source of Nutrients for Weyland Rice. In: International Conference on Organic Matter and Rice. International Rice Research Institute, Los Banas, Laguna, Philippines, 1982.

14. Regar PL, Rao SS, Vyas SP. Crop-residue management for increased wheat (Triticum aestivum) production under saline soils of arid fringes. Indian Journal of Agricultural Sciences. 2005; 75(2):83-6.

15. Singh Y, Singh B, Meelu OP, Khind CS. Long-term Effects of Organic Manuring and Crop Residues on the Productivity and Sustainability of Rice-Wheat Cropping System in Northwest India, 2000, 149-162

16. Surekha K, Rao KV. Direct and residual effects of organic sources on rice productivity and soil quality of 
Vertisols. Journal of Indian Society of Soil Science. 2009; 57(1):53-57.

17. Subbiah BV, Asija GL. A rapid procedure for the determination of available Nitrogen in soils. Current Science, 1956; 25:259-260.

18. Walkley A, Black CA. An examination of the wet digestion method for determining Soil organic matter and proposed modification of the chromic acid titration method. Soil science. 1934; 37:29-38.

19. Walia SS, Brar SS, Kler DS. Effect of management of crop residues on soil Properties in rice-wheat cropping system. Environment and Ecology. 1995; 13(3):503-507. 